\title{
FAKTOR-FAKTOR PENYEBAB KETERLAMBATAN DISTRIBUSI REKAM MEDIS RAWAT JALAN DI RUMAH SAKIT TK II DUSTIRA CIMAHI
}

\author{
Indri Ismawati ${ }^{1}$, Nurul Aulia Yulianti ${ }^{2}, \operatorname{Irda~Sari~}^{3}$ \\ Politeknik Piksi Ganesha ${ }^{1,2,3}$ \\ indriismawati21@gmail.com ${ }^{1}$, nurulayds1511@gmail.com ${ }^{2}$, irdasari13@gmail.com³
}

Received: 01-07-2021

Revised : 16-07-2021

Accepted: 25-07-2021

\begin{abstract}
Abstrak
Latar Belakang: Salah satu bentuk pelayanan di rumah sakit terutama dibagian rawat jalan yaitu pendistribusian rekam medis yang dapat mempengaruhi kepuasan pasien. Berdasarkan hasil praktek kerja lapangan, diperoleh bahwa terdapat keterlambatan pendistribusian dokumen rekam medis lebih dari 10 menit.
\end{abstract}

Tujuan: Tujuan dari penelitian ini adalah untuk mengetahui faktor-faktor apa saja yang mempengaruhi keterlambatan distribusi rekam medis rawat jalan di Rumah Sakit TK II Dustira Cimahi.

Metode: Metode penelitian yang digunakan adalah penelitian deskriptif dengan pendekatan kualitatif. Metode pengumpulan data yang digunakan adalah menggunakan observasi dan wawancara. Sampel yang digunakan berjumlah 92 berkas rekam medis rawat jalan di Rumah Sakit TK II Dustira Cimahi.

Hasil: Hasil penelitian menunjukan bahwa persentase keterlambatan pendistribusian dokumen rekam medis rawat Jalan di Rumah Sakit TK II Dustira Cimahi periode 21-23 Juni 2021 mengalami keterlambatan 48\% dari sampel 92 dokumen rekam medis rawat jalan sedangkan 52\% dokumen rekam medis rawat jalan sudah memenuhi standar waktu yang ditentukan.

Kesimpulan: Faktor yang mempengaruhi keterlambatan pendistribusian dokumen rekam medis rawat jalan yaitu karena kurangnya sumber daya manusia dibagian distribusi, kurangnya rak penyimpanan dokumen rekam medis dan tugas rangkap yang dilakukan oleh petugas distribusi rekam medis.

Kata Kunci: persentase pendistribusian rekam medis; dokumen rekam medis; faktor penyebab keterlambatan distribusi rekam medis.

\begin{abstract}
Background: One form of service in hospitals, especially in the outpatient department, is the distribution of medical records that can affect patient satisfaction. Based on the results of the field work practice, it was found that there was a delay in the distribution of medical record documents for
\end{abstract}


more than 10 minutes.

Objective: The purpose of this study was to determine what factors affect the delay in the distribution of outpatient medical records at the TK II Dustira Cimahi Hospital.

Methods: The research method used is descriptive research with a qualitative approach. The data collection method used is using observation and interviews. The sample used was 92 outpatient medical record files at TK II Dustira Cimahi Hospital. The results showed that the percentage of delays in the distribution of outpatient medical record documents at the TK II Dustira Cimahi Hospital for the period 21-23 June 2021 experienced a delay of 48\% from a sample of 92 outpatient medical record documents while $52 \%$ of outpatient medical record documents have met the specified time standard.

Conclusion: Factors that affect the delay in the distribution of outpatient medical record documents are due to the lack of human resources in the distribution section, the lack of medical record document storage racks and duplicate tasks carried out by medical record distribution officers.

Keywords: percentage of medical record distribution; medical record documents; factors causing delay in medical record distribution.

Correspondence: Indri Ismawati Email: indriismawati21@gmail.com

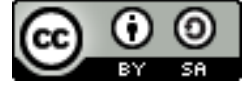

\section{PENDAHULUAN}

Pelayanan publik merupakan kegiatan pemenuhan kebutuhan pelayanan sesuai dengan peraturan perundang-undangan bagi setiap warga negara dan penduduk atas barang, jasa, dan pelayanan administratif yang disediakan oleh penyelenggara pelayanan publik (Indonesia, 2009). Salah satu penyelenggara pelayanan publik dalam hal ini adalah Rumah Sakit, yang dibentuk untuk melaksanakan kegiatan pelayanan publik di bidang kesehatan. Pelayanan kesehatan adalah tersedianya pelayanan yang berhasil guna dan berdaya guna yang tersebar secara merata diseluruh Indonesia. Dengan demikian terwujudnya derajat kesehatan masyarakat yang optimal dapat tercapai bagi setiap orang sehingga dapat hidup produktif secara sosial dan ekonomis (Rahmah \& Wahyuni, 2015).

Rumah sakit merupakan sarana pelayanan kesehatan, tempat berkumpulnya orang sakit maupun orang sehat, dan juga dapat menjadi tempat penularan penyakit serta memungkinkan terjadinya pencemaran lingkungan dan gangguan kesehatan (Kepmenkes, 2004). Rumah sakit memiliki berbagai bentuk pelayanan, salah satunya yaitu pelayanan rawat jalan. Rawat jalan adalah pelayanan medis kepada seorang pasien dan tidak lebih dari 24 jam pelayanan untuk tujuan pengamatan, diagnosis, pengobatan, rehabilitasi, dan pelayanan kesehatan lainnya, tanpa mengharuskan pasien tersebut di rawat inap (Rahmatika, 2004). Upaya untuk meningkatkan pelayanan yang dilakukan oleh Rumah Sakit adalah dengan menyelenggarakan berbagai unit sebagai pelakasana programprogram untuk tercapainya pelayanan berkualitas. Salah satu indikator pelayanan yang berkualitas adalah dengan tercapainya tertib administrasi yang dapat dilihat dari sistem 
pengelolaan rekam medis yang baik. Rumah sakit membutuhkan unit-unit pembantu untuk menjalankan tugasnya, diantaranya adalah unit rekam medis (Budi, 2011)

Rekam Medis adalah berkas berisi catatan dan dokumen tentang pasien yang berisi identitas, pemeriksaan, pengobatan, tindakan medis lain pada sarana pelayanan kesehatan untuk rawat jalan, rawat inap baik dikelola pemerintah maupun swasta (Permenkes, 2008). Rekam medis juga merupakan keterangan baik yang tertulis maupun terekam tentang identitas, anamnesis, penentuan fisik laboratorium diagnosis segala pelayanan dan tindakan medis yang diberikan kepada pasien, dan pengobatan baik yang dirawat inap, rawat jalan maupun yang mendapatkan pelayanan gawat darurat (Depkes, 2008). Secara umum isi Rekam Medis dapat dibagi dalam dua kelompok data yaitu, data medis atau data klinis dan data sosiologis atau data non-medis.

Mutu pelayanan kesehatan adalah derajat kesempurnaan pelayanan kesehatan yang sesuai dengan standar profesi dan standar pelayanan dengan menggunakan potensi sumber daya yang tersedia di rumah sakit atau puskesmas secara wajar, efisien dan efektif serta diberikan secara aman dan memuaskan sesuai norma, etika, hukum, dan sosial budaya dengan memperhatikan keterbatasan dan kemampuan pemerintah, serta masyarakat konsumen (Bustami, 2011).

Pelayanan rekam medis yang baik dan bermutu tercermin dari pelayanan yang ramah, cepat, serta nyaman. Masa kerja mempengaruhi kinerja petugas rekam medis, semakin lama bekerja maka semakin cepat dalam melayani pengambilan berkas rekam medis sehingga dapat meminimalisir waktu tunggu pasien (Siagian, 2008). Mutu pelayanan kesehatan bisa disebut baik jika di dukung oleh sistem pelayanan rekam medis yang cepat dan tepat waktu sesuai dengan ketentuan yang ditetapkan oleh rumah sakit.

Salah satu bentuk pelayanan di rumah sakit terutama dibagian rawat jalan yaitu pendistribusian rekam medis. Sistem pendistribusian yang baik adalah sistem pendistribusian yang cepat, baik dan efisien (Hatta, 2008). Distribusi rekam medis adalah kegiatan mencatat nomor rekam medis yang telah di cari oleh petugas filling pada buku ekpedisi sesuai poli yang dituju, kemudian rekam medis tersebut diantarkan menuju poli oleh petugas distribusi rekam medis. Apabila waktu dalam pendistribusian rekam medis lama, maka akan menghambat terhadap pelayanan kesehatan yang diberikan kepada pasien dan menjadi salah satu indikator dalam mengukur kepuasan pasien.

Dalam rangka mengetahui lebih mendalam terkait hal tersebut, peneliti mengambil kajian tentang faktor-faktor yang mempengaruhi keterlambatan pendistribusian dokumen rekam medis rawat jalan di Rumah Sakit TK II Dustira Cimahi.

\section{METODE PENELITIAN}

Jenis penelitian ini adalah penelitian deskriptif yaitu penelitian yang dilakukan untuk menjelaskan dan menggambarkan secara sistematis, masalah, fakta, keadaan, fenomena, variabel, program atau informasi yang diperlukan dari lapangan dengan pendekatan kualitatif (Miharti, 2018). Peneleitian deskriftif juga merupakan suatu metode untuk mendeskripsikan tentang sesuatu keadaan secara objektif, memecahkan dan menjawab permasalahan yang sedang di hadapi pada situasi sekarang. Menurut (Sugiyono, 2016). Metode penelitian kualitatif adalah metode penelitian yang digunakan untuk meneliti pada kondisi obyek yang alamiah dimana peneliti adalah sebagai instrumen kunci. Penelitian ini menjelaskan atau mendeskripsikan tentang pendistribusian dokumen rekam medis pasien rawat jalan di Rumah Sakit TK II Dustira Cimahi dan menjelaskan tentang faktor apa saja yang mempengaruhi keterlambatan distribusi rekam medis rawat jalan di Rumah Sakit TK II Dustira Cimahi. Subjek dalam penelitian ini yaitu, petugas distribusi rekam medis. Objek penelitian atau sasaran penelitian adalah berkas rekam medis rawat jalan Rumah Sakit TK II Dustira Cimahi. Metode pengumpulan data yang digunakan adalah menggunakan observasi. dan wawancara. Menurut (Saryono, 2010), 
wawancara dapat dilakukan secara terstruktur maupun tidak terstruktur dan dapat dilakukan dengan langsung atau menggunakan telepon. Menurut (Notoatmodjo, 2010), observasi yaitu suatu prosedur terencana, antara lain mencatat jumlah dan taraf aktifitas berhubungann masalah penelitian Penelitian ini menggunakan teknik analisis kualitatif dengan memaparkan hasil observasi dan wawancara yang telah dilakukan, serta dihasilkan upaya rekomendasi sejalan dengan penelitian (Azis \& Deharja, 2020).

\section{HASIL DAN PEMBAHASAN}

\section{A. Hasil Penelitian}

Penelitian ini dilakukan pada tanggal 21-23 Juni 2021 di Rumah Sakit TK II Dustira Cimahi. Berdasarkan hasil survey Praktek Kerja Lapangan yang dilakukan di Rumah Sakit TK II Dustira Cimahi terdapat masalah mengenai keterlambatan pendistribusian rekam medis. Pengambilan sampel dihitung dari jumlah dokumen rekam medis rawat jalan periode tanggal 21-23 Juni 2021 dengan jumlah 1.196 pasien rawat jalan. Sampel yaitu bagian dari keseluruhan objek yang diteliti dan dianggap mewakili keseluruhan populasi. Perhitungan jumlah sampel menggunakan rumus Slovin (Sevilla et. aI. 2007) dalam (Medis, n.d.).

$$
\begin{aligned}
& \mathrm{n}=\frac{N}{1+N\left(d^{2}\right)} \\
& \mathrm{n}=\frac{1.196}{1+1.196\left(0.1^{2}\right)} \\
& \mathrm{n}=\frac{1.196}{1+1.196(0,01)} \\
& \mathrm{n}=\frac{1.196}{1+11,96} \\
& \mathrm{n}=\frac{1.196}{12,96} \\
& \mathrm{n}=92,28 \\
& \mathrm{n}=92 \text { sampel }
\end{aligned}
$$

Berdasarkan hasil perhitungan tersebut diperoleh sampel berkas rekam medis pasien rawat jalan sebanyak 92 sampel.

Tabel 1. Jumlah Sampel Rekam Medis

\begin{tabular}{cccc}
\hline No & $\begin{array}{c}\text { Interval Waktu } \\
(\text { Menit })\end{array}$ & DRM Rawat Jalan & Keterangan \\
\hline 1 & $<10$ Menit & 53 & Tepat \\
2 & $>10$ Menit & 39 & Tidak tepat \\
\hline & & $\mathbf{9 2}$ & \\
\hline
\end{tabular}

Sumber refrensi data tabel: Data Primer tanggal 21-23 Juni 2021

\section{B. Pembahasan}

Berdasarkan tabel dapat diketahui bahwa pendistribusian rekam medis rawat jalan di Rumah Sakit TK II Dustira Cimahi yang kurang dari 10 menit berjumlah 53 dokumen rekam medis, sedangkan pendistribusian rekam medis rawat jalan yang lebih dari 10 menit berjumlah 39 dokumen rekam medis. Berdasarkan tabel kategorisasi pendistribusian dokumen rekam medis rawat jalan di Rumah Sakit TK II Dustira Cimahi periode 21-23 Juni 2021 dapat digambarkan dalam diagram sebagai berikut: 


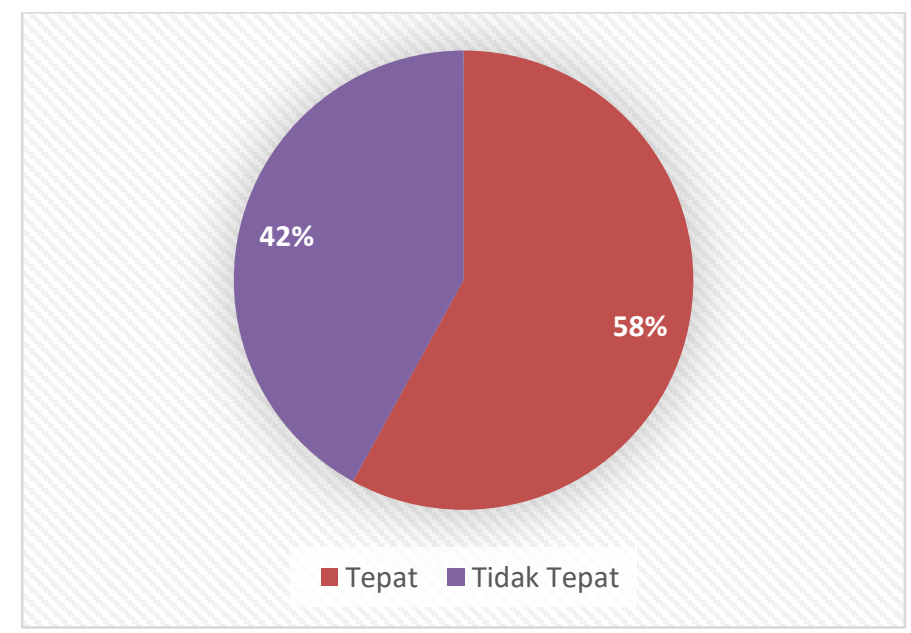

Gambar 1. Diagram Persentase

Berdasarkan diagram diatas dapat disimpulkan bahwa persentase pendistribusian dokumen rekam medis rawat jalan di Rumah Sakit TK II Dustira Cimahi periode 21-23 Juni 2021 mengalami keterlambatan 48\% dari sampel 92 dokumen rekam medis rawat jalan sedangkan 52\% dokumen rekam medis rawat jalan sudah memenuhi standar waktu yang ditentukan. Faktor yang mempengaruhi keterlambatan pendistribusian dokumen rekam medis rawat jalan yaitu karena kurangnya sumber daya manusia dibagian distribusi, kurangnya rak penyimpanan dokumen rekam medis dan tugas rangkap yang dilakukan oleh petugas distribusi rekam medis.

\section{KESIMPULAN}

Persentase pendistribusian dokumen rekam medis rawat jalan di Rumah Sakit TK II Dustira Cimahi periode 21-23 Juni 2021 mengalami keterlambatan 48\% dari sampel 92 dokumen rekam medis rawat jalan sedangkan 52\% dokumen rekam medis rawat jalan sudah memenuhi standar waktu yang ditentukan.

Kurangnya jumlah petugas distribusi rekam medis di Rumah Sakit TK II Dustira Cimahi mengakibatkan tingginya beban kerja yang di lakukan. Kurangnya rak penyimpanan sehingga dokumen rekam medis masih banyak Yang tercecer menyulitkan petugas untuk mencari dokumen rekam medis, sehingga memperlambat pendistribusian dokumen rekam medis rawat jalan.

Dokumen rekam medis yang sulit ditemukan membuat petugas distribusi ikut serta untuk mencari dokumen rekam medis tersebut sehingga petugas distribusi merangkap menjadi petugas filling.

\section{BIBLIOGRAFI}

Azis, F., \& Deharja, A. (2020). Analisis Faktor Penyebab Keterlambatan Pendistribusian Dokumen Rekam Medis ke Poli Bedah di RSUPN Dr. Cipto Mangunkusumo. $J$ REMI: Jurnal Rekam Medik Dan Informasi Kesehatan, 1(4), 424-430.

Budi, S. C. (2011). Manajemen unit kerja rekam medis. Yogyakarta: Quantum Sinergis Media.

Bustami, M. S. (2011). Penjaminan mutu pelayanan kesehatan \& akseptabilitasnya. 
Depkes, R. I. (2008). Standar Pelayanan Minimal Rumah Sakit. Jakarta: Departemen Kesehatan RI, 18.

Hatta, G. R. (2008). Pedoman Manajemen Informasi Kesehatan di sarana pelayanan kesehatan. Jakarta: Universitas Indonesia.

Indonesia, P. R. (2009). Undang-Undang RI No. 25 Tahun 2009 tentang Pelayanan Publik. Lembaran Negara RI Tahun 2009. Sekretariat Negara. Jakarta, 1-77.

Kepmenkes, R. I. (2004). Keputusan Menteri Kesehatan Republik Indonesia Nomor 1204. MENKES/SK/X/2004 Tentang Persyaratan Kesehatan Lingkungan Rumah Sakit.

Medis, L. W. P. R. (n.d.). Tinjauan Lama Waktu Pendistribusian Rekam Medis Pada Pasien Rawat Jalan Di Rsu Imelda Pekerja Indonesia Medan Tahun 2016.

Miharti, R. (2018). Faktor Penyebab Keterlambatan Penyediaan Berkas Rekam Medis Pasien Rawat Jalan Berdasarkan Standar Pelayanan Minimal Di Rsud Tidar Kota Magelang Tahun 2018.

Notoatmodjo, S. (2010). Metode Penelitian Kesehatan. Jakarta. Rineka Cipta.

Permenkes, R. I. (2008). No 269/Menkes/Per/III/2008 tentang Rekam Medis. Jakarta: Menteri Kesehatan Reupublik Indonesia.

Rahmah, E. R., \& Wahyuni, I. (2015). Faktor-Faktor Yang Mempengaruhi Kecepatan Pengambilan Dokumen Rekam Medis Rawat Jalan RSUD dr. Soekardjo Kota Tasikmalaya 2014. Jurnal Persada Husada Indonesia, 2(5), 32-44.

Rahmatika, Y. (2004). Analisis Tingkat Kepuasan Pasien Rawat Jalan Terhadap Kualitas Pelayanan (Studi Kasus: Rumah Sakit Pusat Pertamina). IPB (Bogor Agricultural University).

Saryono, A. (2010). Metodologi penelitian kualitatif dalam bidang kesehatan. Yogyakarta: Nuha Medika, 98-99.

Siagian, P. S. (2008). Manajemen Sumber Daya M anusia, jakarta: Bumi Askara. 2000. Teori Dan Praktek Kepemimpinan.

Sugiyono. (2016). Metode Penelitian Kuantitatif, Kualitatif dan R\&D. PT Alfabet.

(C) 2021 by the authors. Submitted for possible open access publication under the terms and conditions of the Creative Commons Attribution $\quad(\mathrm{CC} \quad \mathrm{BY} \quad \mathrm{SA}) \quad$ license (https://creativecommons.org/licenses/by-sa/4.0/). 